\title{
Can Credit Program Improve Agricultural Productivity? Evidence from Indonesia
}

\author{
Gilang Wirakusuma ${ }^{1, *}$ and Irham Irham $^{1}$ \\ ${ }^{1}$ Department of Agricultural Socio-economics, Universitas Gadjah Mada
}

\begin{abstract}
Agricultural credit is a vital policy in improving farm performance since agricultural households face financial constraints in their business. This study aims to: (1) examine the impact of credit $\mathrm{s}$ on agricultural productivity while investigating the difference in impact generated by loans originating from governmental program loans and nonprogram loans and; (2) identify the characteristics of farm households that influence the use of credit in their business. This study employed crosssectional micro-data at the household level drawn from the 2013 Indonesian Agricultural Census, in which 86,922 rice farm households were randomly selected as the research sample. The model was examined by using Two-Stage Least Square to avoid the selectivity bias. Results show that credit originated from government programs has a small impact on agricultural productivity, although the significant correlation appears. Furthermore, the use of credit, both government programs, and nonprograms are determined by socio-economic aspects, agricultural subsidy, perceptions on risks, and perception on-farm profitability. Based on the results, the provision of credit to agricultural activities has to be supported by the provision of supporting incentives, such as agricultural counseling and irrigation facilities, in order to boost agricultural productivity effectively.
\end{abstract}

\section{Introduction}

The agricultural sector still holds a vital role for the Indonesian economy because this sector contributes around $13.5 \%$ to the Gross Domestic Product (GDP) and creates employment for $33.5 \%$ of the total workforce in Indonesia [1]. In addition, increasing agricultural productivity growth and encouraging development programs related to the agricultural sector has proven to be able to reduce poverty levels in Indonesia [2,3], especially in rural areas where $58 \%$ of the sparse population exists. Furthermore, $75 \%$ of the poor in rural areas depend on their livelihoods for various activities in the agricultural sector [4].

Increased agricultural productivity cannot be carried out partially by the main actors of farming, namely farm households. This process requires intervention in the form of incentives to provide an accelerating effect for farm households that have limited resources.

\footnotetext{
*Corresponding author: gilang_wirakusuma@ugm@ugm.ac.id
} 
In some literature, it is stated that increasing agricultural productivity requires adequate capital accumulation. Therefore, providing credit to farm households, especially small farmers who have limited financial resources, is an essential requirement. Credit can increase the capitalization of farmers to allocate more resources, especially to adopt better technology and invest more profitably [5-7].

In order to improve farming performance, regardless of the production scale, previous studies have concluded that it is very important to provide affordable credit. The role of credit to encourage the increasing agricultural productivity is reflected by its ability to determine the level of technological change and increase technical efficiency in agricultural operations. An understanding of the role of credit is vital because, along the agribusiness chain, technological improvement is crucial in the process of agricultural commercialization [8]. Previous studies also found evidence that the use of credit has a positive and significant effect on the adoption of better agricultural production technologies among farmers and reducing technological gaps used by farmers and technology available in the market, which is very important to increase agricultural productivity [9-11].

Meanwhile, although credit is significant to encourage agricultural productivity, not all farm households can access or use it, especially if there is limited credit funds availability. Farmer use of credit is not a stand-alone variable but is the result of determinants that influence whether farm households use it or can access it. Generally, credit utilization can be determined by household socio-economic characteristics [12].

The provision of credit to farm households in Indonesia has been widely implemented in various forms of programs, both implemented by the government and by nongovernmental organizations. Credit programs implemented by the government include Farmer Business Loans (KUT), Food Security Loans (KKP), Group Business Capital Strengthening (PMUK), as well as several multi-sectoral credit programs that are specific to small-scale economic enterprises. In addition to the government, financial institutions, both bank and non-bank, also provide commercial loans for farming.

Although the government and financial institutions have provided many credit programs, farm households also tend to access credit outside the programs provided by the government. If they need additional capital when the available programs do not allow access, farm households will choose to access credit from other sources, for example, from families, relatives, and other loan providers that are generally informal. Access to credit that is not through farm-specific credit programs tends to be high-interest loans if they do not come from families or relatives [13].

This study aims to: (1) examine the impact of credit used by farm households on agricultural productivity while investigating the difference in impact generated by loans originating from governmental program loans and non-program loans and (2) to identify the characteristics of farm households that influence the use of credit in their business. This study accommodates the problem of selection bias, which refers to the limited availability of credit funds and competition factors for accessing credit. In the Indonesian context, where the majority of farmers are small farmers, the provision of credit is closely related to the limited scale of agriculture and risk management by farmers so that the distribution and utilization of credit are not random but based on the character of each farmer. 


\section{Materials and Methods}

\subsection{Data}

This study employed cross-sectional micro-data at the household level drawn from the 2013 Indonesian Agricultural Census, in which 86,922 rice farm households were randomly selected as the research sample.

\subsection{Analytical framework}

The objective of this study is to identify the impact of credit on agricultural productivity at the level of farm households in the context of rice farming. The credit observed in this study is the amount of credit used in rice farming activities so that the bias in the purpose of using credit can be eliminated. In general, the characteristics of farm households determine their behavior in accessing and using credit. This study excludes the possibility that farm households are more productive, not because of additional capital from credit. Also, aspects of environmental quality differences that cause variations in farm productivity in each farm household are not included in the analysis.

Agricultural credit providers will consider various criteria based on the characteristics of each farm household so that the determination of farm households that receive or access credit is not random. Assuming that the credit supply is limited to all farm households, the model in the analysis must accommodate the selection bias associated with the determination of credit recipients. By adopting the model used by Khandker and Faruqee (2003) and Akudugu (2012), the formula used to investigate the impact of credit use on rice farm productivity in Indonesia is as follows:

$$
y_{i j}=\beta_{y} X_{i j}+\gamma C_{i j}+\mu_{j}+\varepsilon_{i}^{y}
$$

Where $y_{i j}$ is the productivity of rice farming in household $\mathrm{i}$ in province $\mathrm{j}$ as measured by the ratio of the gross value of product per unit area of land, $X_{i j}$ represents a variety of characteristics that can be observed in each farm household, $C_{i j}$ shows the amount of credit used by each farm households, and $\mu_{j}$ are unobservable factors that also determine productivity. Meanwhile, $\beta_{y}$ and $\gamma$ are parameters of the independent variables and $\varepsilon_{i j}^{y}$ show specification errors that reflect factors outside the model that affect $y_{i j}$. The magnitude of the error varies across households and is determined as:

$$
E\left(\varepsilon_{i j}^{y} \mid X_{i j}, C_{i j}, \mu_{j}\right)=0
$$

In specification (1), it is possible to measure the impact of credit usage on productivity with $\gamma$ without producing bias. However, $\mu_{j}$, an unobserved variable, has the potential to be associated with $C_{i j}$, so that selection bias occurs. Furthermore, $\mu_{j}$, variables that indicate factors that determine farmers' willingness to use credit are difficult to observe by researchers. Thus, the use of ordinary least square (OLS) to determine the results of equation (1) will produce inconsistent and bias estimation.

The Instrument Variable (IV) approach was used in this study to overcome the selection bias generated from the specifications in equation (1). To overcome endogeneity through the IV approach, Two-Stage Least Square (TSLS) is a suitable analysis tool [15]. In the context of this study, TSLS was carried out by applying two procedures. The first step of this procedure is intended to identify the determinants of credit use, which are represented 
by the characteristics of farm households through OLS. Instrument variables at this stage are assumed only to affect the amount of credit accessed and used by farm households, not to affect productivity. Furthermore, the credit value predicted from the estimation results in the first stage will be used in the second phase of the analysis procedure to correct the specification bias. To conduct the first phase of analysis, the formulation is:

$$
C_{i j}=\beta_{c} X_{i j}+\theta Z+\varepsilon_{i j}^{c}
$$

On the left side of the equation, $C_{i j}$ shows the amount of credit used by farm households. Meanwhile, on the right-hand side of the equation, $X_{i j}$ represents the characteristics of farm households, $Z$ represents the instrument variable. Furthermore, $\beta_{c}$ and $\theta$ show unknown parameters and $\varepsilon_{i j}^{c}$ are a random error from the unmeasured determinants, which follows:

$$
E\left(\varepsilon_{i j}^{c} \mid X_{i j}, Z,\right)=0
$$

In the specification of equation (3), the involving instrument variable $(Z)$ is an important part of overcoming selection bias in determining the predicted value of the credit variable. The price of credit, in this case, the interest rate, is an easy variable to involve. However, the value of the interest rates paid by each recipient of credit is very likely to be the same, so it is not appropriate to explain the credit variables at this stage of the analysis.

The assumptions used by [10] were adopted in this study, with three assumptions to determine the instrument variables in the specification of equation (3). The first assumption is that the amount of funds available to be transferred as a credit to rice farming households is constant and limited. The second assumption is that there is an excessive demand for credit, which causes competition among farm households to access credit. The final assumption in the specification (3) is that there are many borrowers, at different levels, competing for loan funds. In this study, the scale of competition is simplified with the assumption that competition between farm households is at the provincial level. Based on these assumptions, the number of farm households that access credit tends to be determined by competition for credit and the amount of the available fund for credit.

In addition, loans that are accessed by farm households are not only determined by the characteristics of each farm household but are also influenced by characteristics possessed by other farm households, which are assumed to seek the same loan also. Thus, the appropriate instrument variables for estimating credit equations are competitors' characteristics. For the availability of scarce loan funds, lenders will consider the characteristics of farm households, and in this study, are represented by land owned by the borrower because land ownership is related to asset information, which is usually used as loan collateral. Thus, in the model, average loans at the provincial level are included to show the limited availability of funds in each region where farm households compete. Meanwhile, the ratio between the area of land owned by one farmer household and the average owned land size at the provincial level is used in the study to estimate the competitive power of each farmer household in accessing credit. Finally, equation (3) is adjusted according to the formulation as follows:

$$
C_{i j}=\beta_{c} X_{i j}+\delta \bar{C}_{J}+\rho L_{i / j}+\varepsilon_{i j}^{c}
$$

Where $C_{i j}$ is the amount of credit used by farm households in province j, meanwhile $X_{i j}$ represents the characteristics of farm households i in province $\mathrm{j}, C_{j}$ indicates the average value of the amount of credit in province $\mathrm{j}$, and $L_{i / j}$ shows the ratio of land held by farm 
households $i$ and the average area of land ownership of all farm households in the province $\mathrm{j}$. Furthermore, $\beta_{c}, \delta$, and $\rho$ are unknown parameters and $\varepsilon_{i j}^{c}$ is a specification error.

Thus, the estimation in the first stage is transformed as:

$$
\hat{C}_{i j}=\hat{\beta}_{c} X_{i j}+\hat{\delta} \bar{C}_{j}+\hat{\rho} L_{i / j}
$$

Where $\hat{C}_{i j}$ is the estimated value of the amount of credit used by farm households i in province $\mathrm{j}$, while $\hat{\beta}_{c}, \hat{\delta}_{\hat{n}}$, and $\hat{\rho}$ are unknown parameters. Meanwhile, $X_{i j}, \bar{C}_{j}, L_{i / j}$ were defined earlier. Furthermore, the productivity specified in equation (1) is adjusted to:

$$
y_{i j}=\beta_{y} X_{i j}+\gamma \hat{C}_{i j}+\varepsilon_{i}^{y}
$$

\subsection{Empirical Framework}

Based on the analytical framework presented earlier, in this study, the relevant variables are used as explanatory variables in the credit equation and the productivity equation. In the first phase, structural equation, credit equations, information about socio-economic characteristics, policies, perceptions of farm performance, and instrument variables are included in the equation. Socio-economic variables are represented by age, level of education, the gender of household heads, membership in farmer groups, and other relevant information. The policy factor introduced to explain the credit variable is the subsidy policy received by each farm household. Variable perceptions of farm performance are represented by perceptions about the risk of pests and plant diseases, the risk of disasters or weather anomalies, and the potential profitability of farming. Furthermore, the instrument variables used to eliminate the selectivity of agricultural credit are credit availability and the scale of agricultural land ownership.

In the second equation, namely the productivity equation, in addition to the credit variables tested as a determinant of productivity, variables related to aspects of agricultural input, infrastructure, and capacity building programs are also included in the equation. Labor, land area and equity are used as a representation of agricultural input variables. Agricultural infrastructure variables are represented by the availability of irrigation in rice farming. Meanwhile, the capacity building program in rice farming is represented by access to or availability of agricultural extension services and the participation of the Integrated Crop Management Field School (SLPTT).

In this study, credit variables are separated based on sources of credit accessed by farm households, namely government program loans, and non-government program loans. Credit categorized as government program credit is credit obtained from funds allocated for rice farming production activities originating from government programs by providing loan funds for agricultural activities. Meanwhile, non-government program credits are loans obtained by farm households, which are used for rice production but come from lenders that are not explicitly intended for rice production or other agricultural activities. Sources of non-government program credit can come from families, relatives, and formal or nonformal financial institutions. 
Tabel 1. Operational Variables

\begin{tabular}{|c|c|}
\hline Variable & Description and Measurement \\
\hline \multicolumn{2}{|l|}{ a. First stage estimation } \\
\hline \multicolumn{2}{|l|}{ Credit variable } \\
\hline Government program credit & $\begin{array}{l}\text { Amount of farm credit from the government } \\
\text { (IDR) }\end{array}$ \\
\hline Non-program credit & $\begin{array}{l}\text { Amount of farm credit not from government } \\
\text { programs (IDR) }\end{array}$ \\
\hline \multicolumn{2}{|l|}{ Socio-economic characteristics } \\
\hline Age & Age of household head (year) \\
\hline Commercialization rate & The proportion of the sold yields (\%) \\
\hline Male head household sex & $=1$ if male $;=0$ if female \\
\hline High school education & $\begin{array}{l}=1 \text { if graduated from high school; }=0 \text { if } \\
\text { under high school }\end{array}$ \\
\hline Income class & $\begin{array}{l}=1 \text { if income is above average; }=0 \text { if below } \\
\text { average }\end{array}$ \\
\hline Farmer group membership & $=1$ if a member; $=0$ if not a member \\
\hline \multicolumn{2}{|l|}{ Subsidy Policy } \\
\hline subsidies / grants & $=1$ if received; $=0$ if not received \\
\hline \multicolumn{2}{|l|}{ Perception of the farm } \\
\hline $\begin{array}{l}\text { Perception of the risk of pest / plant } \\
\text { disease attacks }\end{array}$ & $=1$ if at risk of pest attack; $=0$ if not at risk \\
\hline $\begin{array}{l}\text { Perception of the risk of disaster or climate } \\
\text { anomaly impact }\end{array}$ & $=1$ if at risk of disaster; $=0$ if not at risk \\
\hline Prediction of farm profitability & $=1$ if it is profitable $;=0$ if it is not profitable \\
\hline \multicolumn{2}{|l|}{ Instrument Variables } \\
\hline Land tenure ratio & $\begin{array}{l}\text { The ratio of authorized land area to the } \\
\text { average provincial land area }\end{array}$ \\
\hline Credit availability & $\begin{array}{l}\text { The average amount of farm credit at the } \\
\text { provincial level (IDR) }\end{array}$ \\
\hline \multicolumn{2}{|l|}{ b. Second stage estimation } \\
\hline \multicolumn{2}{|l|}{ Agricultural productivity } \\
\hline Rice farm productivity & $\begin{array}{l}\text { Nilai bruto produksi padi per hektar lahan } \\
(0,000 \mathrm{IDR} / \mathrm{ha})\end{array}$ \\
\hline \multicolumn{2}{|l|}{ Agricultural input } \\
\hline Land area & Total harvested area for rice $\left(\mathrm{m}^{2}\right)$ \\
\hline Labor & Total workforce (day person) \\
\hline Equity & Amount of equity used for rice farm (IDR) \\
\hline \multicolumn{2}{|l|}{ Infrastructure \& Programs } \\
\hline Irrigation & $=1$ if irrigated; $=0$ if without irrigation \\
\hline Agricultural extension services & $=1$ if available $;=0$ if not available \\
\hline Integrated Rice Management Field School & $=1$ if the participant $=0$ if not a participant \\
\hline
\end{tabular}




\section{Results and Discussion}

\subsection{Descriptive Statistics}

Descriptive statistics in this study (Table 2) show that the average value of government program credits used by farm households in rice farming is smaller than the nongovernment program credits. It shows that the availability of government program credit is very limited, although the interest of farmers to use government credit is relatively large for the relatively low loan interest. This fact can be caused by the nature of program credit, which is only channeled at specific times/periods and given the limitations of the government budget. Meanwhile, non-program loans are relatively available and can be accessed at any time as long as the borrower can meet the loan requirements, including relatively high-interest rates.

The socio-economic aspect is one that is studied to explain the variable use of credit. The gender of the rice farm household heads is dominated by the male one, and the average age is around 49 years. This figure shows that mature men relatively dominate that decision making in farm households. Meanwhile, in terms of education level, the majority of household heads of rice farmers did not complete formal high school (equivalent) or equivalent education. This fact indicates that the majority of farmers have low education. Concerning the use of credit, this relatively low level of education causes the limited ability to understand all the requirements and risks that are part of the distribution of loan funds.

The next socio-economic aspect is the income class. In this study, the income class is determined by a comparison between the actual income of each farm household and the average income of all farm households. Based on this classification, most farmers are households with low-income classes. Furthermore, information about this income class confirms that agricultural credit tends to be attractive to low-income households who have financial limitations for agricultural production activities.

The descriptive analysis also shows that most farmers receive subsidies for the rice farm. Subsidies are policy instruments that provide flexibility and incentives for farm households to produce expansive power in managing rice farms. With the increased drive to expand rice production capacity, farm households are expected to increase capital by using credit.

Perceptions of risk and profitability are essential indicators to explain the behavior/decisions of farm households in using credit. The farm households stated different things related to the risk of rice farming. Most farmers have the perception that their rice farms are at risk of being affected by disasters or climate anomalies. Meanwhile, only about $30 \%$ of the households state that rice farm has the risk of being attacked by plant pests (OPT). The difference in risk perception is determined by handling each risk, where farmers cannot control the risks associated with disasters or climate anomalies, so the perception of their impact on farming is relatively high. On the other hand, around $47.4 \%$ of the sample stated that rice farming would be more profitable in the following season. The perception that increased profitability will provide impetus to farm households to increase capital capacity through the use of credit in order to increase profits.

Information on agricultural inputs, infrastructure, and agricultural programs have been used in this study as explanatory variables for estimating the productivity of rice farming. In the aspect of agricultural inputs, the land is one of the crucial variables studied in this study. Based on descriptive analysis, the average harvest area of rice farming in all farm households is $4,769 \mathrm{~m} 2$. This area indicates that the scale of production owned by rice farming households in Indonesia is relatively small, which is less than 0.5 ha. Meanwhile, the variables that represent infrastructure in increasing the productivity of rice farming are shown by the existence of an irrigation system, where only $45.5 \%$ of rice farming is 
irrigated. This number is insignificant to support rice productivity improvement, where rice cultivation is very dependent on the management of adequate water resources. The aspects of the agricultural program in this study are associated with the program to increase the capacity and skills of farmers, namely agricultural extension and SLPTT. Only $25.1 \%$ of the sample stated that there was a counseling service available to them, and around $11.1 \%$ of all samples had participated in SLPTT activities. These facts are certainly not ideal figures for improving the performance of the rice farm. This fact indicates that access to skills and capacity building programs in rice cultivation activities can only be provided to a small proportion of rice farming households

Tabel 2. Descriptive statistics of the variables

\begin{tabular}{|l|c|c|}
\hline \multicolumn{1}{|c|}{ Variable } & Standard Deviation & Mean \\
\hline Government program credit & $12,404.28$ & 167,306 \\
\hline Non-program credit & $2,615,832$ & 464,032 \\
\hline Age & 12.00 & 49.39 \\
\hline Commercialization rate & 33.47 & 36.45 \\
\hline Male head household sex & 0.322 & 0.883 \\
\hline High school education & 0.354 & 0.147 \\
\hline Income class & 0.466 & 0.319 \\
\hline Farmer group membership & 0.499 & 0.524 \\
\hline Subsidies / grants & 0.487 & 0.611 \\
\hline $\begin{array}{l}\text { Perception of the risk of pest/plant } \\
\text { disease attacks }\end{array}$ & 0.461 & 0.305 \\
\hline $\begin{array}{l}\text { Perception of the risk of disaster or } \\
\text { climate anomaly impact }\end{array}$ & 0.480 & 0.639 \\
\hline Prediction of farm profitability & & 0.473 \\
\hline Land tenure ratio & 0.499 & 1.001 \\
\hline Credit availability & 0.966 & 625,159 \\
\hline Rice farm productivity & 540,992 & $2,257.55$ \\
\hline Land area & $1,528.17$ & $4,769.33$ \\
\hline Labor & $5,150.25$ & 33.43 \\
\hline Equity & 31,15 & $5,839,218$ \\
\hline Irrigation & $7,199,560$ & 0.455 \\
\hline Agricultural extension services & 0.498 & 0.251 \\
\hline $\begin{array}{l}\text { Integrated Rice Management Field } \\
\text { School }\end{array}$ & 0.434 & 0.111 \\
\hline Observations (n) = 86,922 & 0.314 & \\
\hline
\end{tabular}

Source: Authors' computation on data set

\subsection{Determinants of Rice Farm Credit Utilization}

Gender, age, and education level are inherent characteristics in each sample. As the results of the analysis, the male household head statistically has a negative correlation and has a significant effect on the use of non-program credit. This fact shows that farm households headed by men tend not to use or reduce the use of non-program credit for the farm operation. The analysis also shows that male-headed households are negatively correlated with the use of program credit, but the relationship is not statistically significant. This finding is very interesting because men usually tend to be more risk-taking than women when it comes to collecting capital through credit.

Moreover, the use of program credit and non-program credit is significantly influenced by the age of the household head, where the older the age of the household head, the lower the use of the program and non-program credit. These results are in line with the findings of previous studies, which found the fact that getting older will tend to avoid or reduce the use 
of credit [9]. The next socio-economic aspect tested as a determining factor of the use of credit is the household head's education level. Findings show that the use of the program and non-program credit will be reduced if the household head has a high level of education, in this case, high school level or above. This fact indicates that the achievement of higher education encourages farmers not to accumulate capital in agricultural activities. This tendency is very reasonable because, with higher education, a person will have a more significant opportunity to get a job outside the agricultural sector that is more profitable or tends to invest outside the agricultural business.

Furthermore, the socio-economic aspects are represented by income class, commercialization, and membership variables in farmer groups. The results of the analysis confirm that the use of the program and non-program credits is also significantly determined by these three variables. When examined from the examination of income class variables, the findings indicate that credit, program, and non-program credit, tend to be more widely used by farm households classified as low-income classes. This result shows that credit is needed by farm households that have relatively limited financial resources in order to increase capital accumulation for their farming. The findings in this study also confirm that program and non-program credit are significantly influenced by variables related to business orientation, namely the level of commercialization. The use of credit in farming will increase if the level of commercialization is high. Commercialization of farming indicates that farms managed by farm households are oriented to meet market needs so that additional capital capacity is needed to increase production. Moreover, participation as members of farmer groups shows different trends in the use of the program and non-program loans by farm households. The use of the non-program credit tends to be used by participating farmers while the government program credit is preferred by farm households that are not members of farmer groups.

A policy aspect, namely subsidies to agriculture, encourages farm households to access and use the program and the non-program credit. Subsidies generate incentives for farm households to provide flexibility in managing capital resources as relatively limited resources.

On the other hand, the use of credit, both the program and the non-program credit, also has a close relationship with the risk perception of unexpected obstacles in the operation of rice farms. The use of credit will be reduced if there is a perception that the farm is at risk of being affected by OPT attacks and disasters or climate anomalies. The potential for pests and disasters will increase the risk of business failure that will make it difficult for farm households to repay loan funds so that this risk perception will hamper the desire of farm households to apply for credit. Meanwhile, related to positive perceptions, the use of the program and the non-program credits will increase if farm households consider the profitability of their farm has the potential to increase in the future. This feature is very reasonable because, along with the optimism for profit, farm households will tend to increase their capital capacity by loan funds in order to increase production.

Instrument variables are also used in the first phase equation specification to accommodate the selection factor in granting loans to farm households. The instrument variables used in the analysis are the ratio of the size of agricultural land owned by each farm household to the average size at the provincial level and the average value of the credit used by farm households in each province. This instrument variable reflects the availability of credit and the strength of farm households to compete for credit in terms of asset ownership, which is usually used for loan collateral. The provincial level is a limitation for competition and the availability of credit funds. The result shows that the use of credit, both the program credit and the non-program credit, is significantly influenced by the two variable instruments. Tests on these instrument variables indicate that the more land owned by farm households compared to other households, the more likely they are to get 
credit. In addition, the greater availability of credit funds, the greater the use of credit by farm households.

Table 3. Estimation of the determinants of credit

\begin{tabular}{|c|c|c|c|c|c|c|}
\hline \multirow[b]{2}{*}{ Variables } & \multicolumn{3}{|c|}{ Government program credit } & \multicolumn{3}{|c|}{ Non-program credit } \\
\hline & Coeficient & \begin{tabular}{l|l} 
t-Stat. \\
\end{tabular} & $p$-value & Coeficient & t-Stat. & $p$-value \\
\hline Constant & $2,442,80$ & 1.027941 & 0.3040 & -620006.2 & -13.00742 & 0.0000 \\
\hline Age & $-1,358.19$ & -3.830762 & 0.0001 & -6080.188 & -8.554990 & 0.0000 \\
\hline $\begin{array}{l}\text { Commercialization } \\
\text { rate }\end{array}$ & $1,803.683$ & 13.22137 & 0.0000 & 6148.562 & 22.48371 & 0.0000 \\
\hline $\begin{array}{l}\text { Male head household } \\
\text { sex }\end{array}$ & $-16,035.99$ & -1.228566 & 0.2192 & -46119.43 & -1.762644 & 0.0780 \\
\hline $\begin{array}{l}\text { High school } \\
\text { education }\end{array}$ & $-52,118.84$ & -4.329380 & 0.0000 & -207072.6 & -8.580876 & 0.0000 \\
\hline Income class & $-27,886.96$ & -2.838503 & 0.0045 & -92736.82 & -4.708889 & 0.0000 \\
\hline $\begin{array}{l}\text { Farmer group } \\
\text { membership }\end{array}$ & $-30,420.49$ & -3.492497 & 0.0005 & 106029.6 & 6.072603 & 0.0000 \\
\hline Subsidies / grants & $43,864.24$ & 4.919307 & 0.0000 & 47959.60 & 2.683162 & 0.0073 \\
\hline $\begin{array}{l}\text { Perception of the risk } \\
\text { of pest / plant disease } \\
\text { attacks }\end{array}$ & $-43,398.39$ & -4.676911 & 0.0000 & -46548.39 & -2.502466 & 0.0123 \\
\hline $\begin{array}{l}\text { Perception of the risk } \\
\text { of disaster or climate } \\
\text { anomaly impact }\end{array}$ & $-9,474.123$ & -1.060526 & 0.2889 & -54952.57 & -3.068656 & 0.0022 \\
\hline $\begin{array}{l}\text { Prediction of farm } \\
\text { profitability }\end{array}$ & $-23,506.13$ & -2.809071 & 0.0050 & 36058.36 & 2.149640 & 0.0316 \\
\hline Land tenure ratio & $149,412.8$ & 31.90537 & 0.0000 & 684388.9 & 72.90495 & 0.0000 \\
\hline Credit availability & 0.072074 & 9.125072 & 0.0000 & 0.838180 & 52.93884 & 0.0000 \\
\hline & $\begin{array}{c}\text { Adj R }^{2}= \\
0.0197\end{array}$ & $\mathrm{n}=86,922$ & $\begin{array}{c}\mathrm{F}=146,6198 \\
(0.0000)\end{array}$ & $\begin{array}{c}\operatorname{Adj~R}^{2}= \\
0.1142 \\
\end{array}$ & $\mathrm{n}=86,922$ & $\begin{array}{c}\mathrm{F}=935.0810 \\
(0.0000)\end{array}$ \\
\hline
\end{tabular}

Source: Authors' computation on data set

\subsection{Impact of Credit on Agricultural Productivity}

In the analysis, the results of the analysis show that the use of government program credit significantly influences rice farm productivity. Productivity will increase when the use of program credit is increased. Meanwhile, the productivity of rice farm is not significantly affected by the non-program credit even though both have a positive correlation. This result is caused by differences in features of the program and the non-program loans. Generally, credit programs specifically for agricultural businesses are accompanied by farm management assistance and supervision so that the program has an expected impact on onfarm performance. Regarding the positive effect of credit on increasing productivity, this result is in line with previous studies regarding the relationship between credit and productivity $[10,16]$. Credit can reduce the burden of capital on household equity, implicitly smooth household income, and explicitly stimulate investment in agricultural activities [9], and this is very important for agricultural production and development [17].

Agricultural input, namely labor, land, and equity, also significantly influence rice farm productivity. The results of the analysis show that productivity tends to decrease if the area of land has been expanded. This finding reconfirms the inverse relationship between agricultural land size and productivity, which has been proven by several previous studies $[10,18,19]$. The amount of labor used is also negatively correlated with the productivity of rice farming. This consequence can occur because of inefficiencies and high labor costs for rice farms.

Furthermore, rice farm productivity is also determined by supporting aspects in the form of infrastructure and agricultural programs. Productivity will be higher if the farm is 
operated on land where the irrigation networks are available. This fact confirms that efforts to increase the productivity of rice farmers need to be accompanied by providing the agricultural infrastructure; in this case, the irrigation facility. Moreover, rice farm productivity can be increased by the provision of agricultural extension services and SLPTT. It can be noted that both programs improve the capacity of farmers' skills in rice cultivation, which are directly related to improving farm performance.

In TSLS analysis, the endogeneity of credit variables was analyzed by the Durbin-WuHausman test (DWH). Residuals generated by the first stage estimation are used in the second stage equation as explanatory variables in the DWH test. This test confirmed the endogeneity of the program and the non-program credit variables. The results showed that the credit variables, both the program and the non-program credit, are endogenous. It means that credit allocation by lenders to rice farm households throughout Indonesia is not random. The results of this test successfully overcome credit variable deviations that cause endogenous selectivity bias [10]. Thus, the analysis using the OLS method to examine the effect of credit usage on productivity will be biased and inconsistent

Table 4. Results of the Productivity Estimation

\begin{tabular}{|c|c|c|c|}
\hline Variable & Coefficient & t-Statistics & Sig. \\
\hline Constant & $2,035.620$ & 188.4838 & 0.0000 \\
\hline Gov. program credit & 0.001362 & 17.69689 & 0.0000 \\
\hline Non-program credit & $5.63 \mathrm{E}-06$ & 0.393890 & 0.6937 \\
\hline Land area & -0.154978 & -101.7701 & 0.0000 \\
\hline Labor & -2.094484 & -14.24220 & 0.0000 \\
\hline Equity & 8.104332 & 0.566602 & 0.5710 \\
\hline Irrigation & $8.71 \mathrm{E}-05$ & 107.8099 & 0.0000 \\
\hline Agricultural extension services & 527.4541 & 55.60344 & 0.0000 \\
\hline $\begin{array}{l}\text { Integrated Rice Management Field } \\
\text { School }\end{array}$ & 205.0795 & 19.43630 & 0.0000 \\
\hline Residual gov. program credit & 7.53E-05 & 20.50532 & 0.0000 \\
\hline Residual non-program credit & $8.39 \mathrm{E}-05$ & 44.93058 & 0.0000 \\
\hline
\end{tabular}

Source: Authors' computation on data set

\section{Conclusion}

infrastructure, and agricultural programs. Productivity will be higher if the farm is operated on land. This study aimed to examine the impact of credit used by farm households on their agricultural productivity while investigating the difference in impact caused by the government program and the non-program credit. Besides, this study was conducted to identify the characteristics of farm households that determine the use of credit on their farm. The results show that the use of government program credit significantly increases agricultural productivity. Although non-program credit has a positive correlation with the productivity of rice farms, its effect on productivity is not statistically significant. This result has implications that agricultural development policies, especially to increase productivity, have to be directed for increasing farmer's household access to credit by government programs. Loans provided to farm households will increase the capacity of their financial resources and will further improve their ability to purchase inputs and better technology. Also, the provision of credit has to be supported by the provision of supporting incentives, such as agricultural counseling and irrigation facilities, both of which have been proven to accelerate the increase in agricultural productivity. Meanwhile, the use of credit, both government programs and non- programs, is determined by socio-economic aspects, agricultural subsidy policies, perceptions of risks, and farm profitability. The findings in 
this study note that the use of credit tends to be used by farmers with low education and income levels. It means that credit funds are needed by farmers whose qualifications are only suitable for working in the agricultural sector and have limited financial resources.

\section{References}

1. World Bank, (2016).

2. D. Susilastuti, Eur. Res. Stud. J. 21, 309 (2018).

3. M. Rusliyadi, A. B. H. M. Jamil, M. Othman, and R. T. Kumalasari, Int. J. Eng. Technol. 7, 5539 (2018).

4. D. A. Anandita and K. Z. Patria, J. Ilmu Ekon. Dan Pembang. 16, (2016).

5. A. G. Osmani and E. Hossain, 3, 163 (2015).

6. M. K. Bashir, Y. Mehmood, and S. Hassan, Pakistan J. Agric. Sci. 47, 407 (2010).

7. E. Wicaksono, in (2014), pp. 20-23.

8. R. Villano, B. Bravo-ureta, D. Sol, and E. Fleming, 66, 129 (2015).

9. M. A. Akudugu, Asian Econ. Soc. Soc. 2, 189 (2012).

10. M. A. Akudugu, Agric. Financ. Rev. 76, 288 (2016).

11. M. Abunga Akudugu, E. Guo, and S. Kwesi Dadzie, J. Biol. Agric. Healthc. 2, 1 (2012).

12. J. Ladvenicová and S. Miklovičová, Visegr. J. Bioeconomy Sustain. Dev. 4, 46 (2015).

13. A. A. Chandio, Y. Jiang, F. Wei, and X. Guangshun, 78, 592 (2018).

14. S. R. Khandker and R. R. Faruqee, Agric. Econ. 28, 197 (2003).

15. Y. A. Adelekan and A. O. Omotayo, J. Dev. Areas 51, 317 (2018).

16. M. K. Bashir, M. Yasir, and H. Sarfraz, Pakistan J. Agric. Sci. 47, 405 (2010).

17. K. Igwe and C. Esonwune, J. Econ. Sustain. Dev. 2, 86 (2011).

18. D. A. Ali and K. Deininger, Land Econ. 91, 317 (2015).

19. C. Carletto, S. Savastano, and A. Zezza, J. Dev. Econ. 103, 254 (2013). 